\title{
TEMPAT PEMANDIAN UMUM
}

\author{
Charlene Vitricia $^{1)}$, Agustinus Sutanto ${ }^{2)}$ \\ 1) Program Studi S1 Arsitektur, Fakultas Teknik, Universitas Tarumanagara, charlene_v37@hotmail.com \\ 2) Program Studi S1 Arsitektur, Fakultas Teknik, Universitas Tarumanagara, afirawiniera@gmail.com

\begin{abstract}
Abstrak
Projek ini mengangkat tema open architecture as a third place, yang kemudian memunculkan sebuah pertanyaan "Bagaimana kita dapat menyatukan beragam orang dari latar belakang yang berbeda ke suatu tempat yang sama?" Pada dasarnya, hal yang menjadi penggerak ataupun motivator bagi seseorang untuk melakukan sesuatu adalah keinginan (needs) dan kebutuhan (wants) individu itu sendiri. Berdasarkan makalah "A Theory of Motivation" dari Abraham Maslow, setiap individu cenderung memenuhi kebutuhan paling dasar sebelum memenuhi kebutuhan di tingkat atasnya. Kondisi beberapa wilayah di Indonesia, khususnya Jakarta sedang menuju krisis salah satu kebutuhan fisiologi, yaitu Air. Jakarta terancam kehilangan seluruh sumber air bersih pada tahun 2040. Bahkan saat ini sumber air yang berasal dari Jakarta hanya 3\% dan sisanya berasal dari Tangerang dan waduk Jatiluhur. Pemerintah melalui PDAM tidak mampu memenuhi seluruh kebutuhan air di Jakarta, sehingga lebih dari 40\% masyarakat Jakarta harus menggunakan air tanah yang kemudian menimbulkan ancaman kedua yaitu terjadinya penurunan muka tanah yang menyebabkan terancam tenggelamnya Jakarta akibat exploitasi air tanah dan meningkatnya bangunan tinggi. Proyek ini berusaha menjawab kebutuhan sosial (third place) yang dapat dikategorikan pada 'tingkat ketiga' (dalam teori hierarki kebutuhan Maslow), melalui penjawaban dari sebuah isu 'kebutuhan tingkat pertama' terlebih dahulu, yaitu kebutuhan fisiologi melalui projek 'Tempat Pemandian Umum'. Dengan mengejar kebutuhan masyarakat, kita dapat menciptakan potensi - potensi titik pertemuan antar individu dan mencapai tempat ketiga yang sesungguhnya.
\end{abstract}

Kata kunci: air; krisis; pemandian; umum

\begin{abstract}
When talking about designing a 3rd place, the first question that came up was "how can we gather various people from different backgrounds, homes, and workplaces into one (same) place? Thing that drives or motivates someone to do something (in this case going to our place) is their wants and needs. Based on A theory of motivation by Abraham Maslow, individuals' most basic needs must be met before they become motivated to achieve higher level needs. The reason behind this proposal is because currently, we're facing a crisis of one of our physiological needs, WATER. In 2040 we're going to lose all source of clean water in Jakarta. Even now the source of water coming from Jakarta is only $3 \%$ and the rest originated from Tangerang and Jatiluhur reservoirs. The government through the PDAM is not able to meet all the water needs in Jakarta, so that more than $40 \%$ of Jakarta citizen don't have other choices, except using ground water which lead to another threat, land subsidence which has threatened to sink Jakarta due to groundwater exploitation and increase of high-rise buildings. Our poor water system management, and wasteful lifestyle bring us closer to the disaster for sure. This project aim to answer social needs (third place) which can be categorized at the 'third level' (in Maslow's hierarchy of motivation theory), through answering an issue of 'lowest level of needs' first, the physiology needs through 'Public Bath' project. By chasing their needs we could create more potential chances for people to intersect each other and achieve the real 3rd place.
\end{abstract}

Keywords: bath; crisis; public; water 


\section{PENDAHULUAN}

Air merupakan kebutuhan fisiologi yang sangat penting untuk mempertahankan kelangsungan hidup manusia, termasuk dalam hal kebersihan dan kesehatan. Namun, pada tahun 2025 diperkirakan sekitar 321 juta jiwa penduduk Indonesia akan mengalami kelangkaan air bersih. Melihat kearah Ibu Kota, penduduk Jakarta yang terus bertambah mencapai sekitar 10 juta jiwa tentunya diikuti oleh meningkatnya kebutuhan air. Pertumbuhan penduduk yang tidak sebanding dengan ketersediaan air dan perilaku masyarakat yang boros air menjadi penyebab utamanya. Di sisi lain peningkatan kebutuhan penyediaan dan pemenuhan air bersih bagi warga Jakarta masih jauh dari memadai.

Badan Geologi, Kementerian Energi Dan Sumber Daya Mineral (ESDM) menyatakan bahwa 80 persen air tanah di wilayah Cekungan Air Tanah (CAT) Jakarta mengalami krisis air bersih atau tidak memenuhi standar Menteri Kesehatan No. 492 tahun 2010. Di Jakarta, sampai tahun 2013, cakupan layanan air bersih baru mampu menjangkau sekitar 38 persen dari total jumlah populasi (10,1 juta jiwa). Jika sepersepuluh dari warga Jakarta dapat mengubah perilakunya untuk menghemat air, maka dapat membantu memperlambat laju krisis air.

Berdasarkan buku A City for All oleh Jo Beall, "kurangnya akses ke layanan dasar seperti air, perawatan kesehatan, dan pendidikan merupakan penyebab sekaligus penanda kemiskinan (poverty) suatu negara", sehingga krisis air bersih bukan hanya tergolong masalah kebersihan (hygiene) dan kesehatan (health), tetapi juga menjadi faktor yang sangat mempengaruhi status ekonomi dan sosial dari suatu negara di mata dunia.

Selain itu, krisis air yang terjadi berdampak pada ketidaksanggupan pemerintah melalui PDAM untuk menyediakan sumber air bersih yang cukup bagi seluruh masyarakat Jakarta, sehingga 40\% masyarakat Jakarta terpaksa menggunakan air tanah yang kemudian menimbulkan ancaman kedua yaitu terjadinya penurunan muka tanah yang menyebabkan terancam tenggelamnya Jakarta akibat exploitasi air tanah dan meningkatnya bangunan tinggi.

Visi dari projek ini adalah membantu pemerintah dalam menemukan solusi krisis air bagi masyarakat, bukan dengan mencari cara untuk mengubah air kotor menjadi air bersih dengan seketika, melainkan mengajukan suatu sistem pemakaian air yang efektif sehingga kuantitas air yang terbatas menjadi cukup, serta menjaga kualitas air sisa pakai sehingga bisa didaur ulang dengan pengolahan air sederhana.

\section{KAJIAN LITERATUR}

\section{Open Architecture as a Third Place \\ Pengertian Third Place}

Ray Oldenburg, seorang sosiolog urban yang menulis tentang pentingnya tempat-tempat pertemuan publik informal, mendefinisikan first place atau "tempat pertama" seseorang sebagai rumah dan tempat tinggal. Sedangkan second place "tempat kedua" adalah tempat kerja - di mana orang mungkin menghabiskan sebagian besar waktu mereka. Maka, tempat ketiga adalah "jangkar" kehidupan berkomunitas dan memfasilitasi serta mendorong interaksi yang lebih luas serta kreatif. Dengan kata lain, "tempat ketiga" Anda adalah di mana Anda bersantai di depan umum, di mana Anda berjumpa dengan wajah-wajah yang akrab dan membuat kenalan baru.

Dalam bangunan komunitas, third place (tempat ketiga) merupakan lingkungan sosial yang terpisah dari dua lingkungan sosial rumah (tempat pertama) dan tempat kerja (tempat kedua). Dalam bukunya yang sangat berpengaruh, The Great Good Place $(1989,1991)$, contoh third place dalam lingkungan seperti gereja, kafe, klub, perpustakaan umum, dan taman.

Oldenburg menunjukkan bagaimana dan mengapa tempat-tempat ini penting bagi kehidupan masyarakat, dengan alasan bahwa bar, kedai kopi, toko umum, dan "tempat ketiga" lainnya adalah pusat demokrasi lokal dan vitalitas masyarakat. 


\section{Esensi Third Place}

Pada bagian awal kata pengantar dari buku The Great Good Place (1991), Ray Oldenberg mengindentifikasikan third place sebagai homes away from home, atau suatu tempat (bukan rumah) dimana individu dapat melakukan aktivitas secara bebas dan merasa nyaman seperti berada di rumah (home) dalam frekuensi tertentu. Third place juga merupakan tempat dimana orang yang tidak berhubungan satu sama lain dapat saling berhubungan (unrelated people relate).

Fungsi yang pertama dan yang utama dari third place adalah menyatukan lingkungan sekitarnya. Ray Oldenberg menggambarkan istilah third place melalui contoh sebuah kantor pos, dimana orang harus berjalan atau berkendara ke sana; dan tempat tersebut tetap dibuka secara hukum, dua puluh empat jam sehari. Meskipun tidak ada tempat duduk yang tersedia, namun tempat tersebut menjadi titik di mana orang-orang bertemu dan bercakap-cakap, setidaknya secara singkat, satu sama lain. Sehingga third place merupakan tempat dimana orang asing dapat bertemu dalam frekuensi tertentu sehingga tidak lagi menjadi asing (where strangers meet each other frequently).

Toko - toko obat (drugstores) menjadi tempat dimana berbagai orang yang tidak saling mengenal dapat berhubungan dengan orang lain dalam frekuensi rata-rata mingguan atau bulanan. Hal ini terjadi karena mereka menawarkan begitu banyak hal, di luar obat-obatan, yang dibutuhkan orang. Biasanya drugstore menempati lokasi (pusat) yang strategis di kota atau lingkungan. Sehingga third place dapat juga didefinisikan sebagai tempat dimana orangorang dengan berbagai kebutuhan berkumpul (people with various needs gathered).

Third place melayani hampir semua orang (everybody) dalam lingkungan dan memiliki "karakter publik" yang menciptakan lingkungan di mana semua orang tahu dan peduli tentang semua orang. Seperti penjaga toko di suatu kawasan yang selalu "mengawasi" keadaan lingkungan sehingga dapat mengingatkan orang tua tentang perilaku anak-anak mereka tanpa harus melibatkan kehadiran polisi untuk kasus tertentu. Mereka juga merupakan orang-orang yang memberikan sambutan pertama bagi pendatang baru dalam lingkungan.

Third place memiliki nilai "do for one another", atau "lakukan untuk satu sama lain", sama seperti yang mereka lakukan untuk keluarga ataupun sahabat. Mereka memberikan hal-hal yang tidak lagi mereka butuhkan; mereka meminjamkan barang-barang yang masih mereka inginkan; mereka melakukan apa yang mereka bisa untuk meringankan kesulitan ketika menimpa "salah satu geng". Ketika seseorang tidak "nampak" selama beberapa hari, seseorang akan berkeliling untuk memeriksa mereka.

\section{Karakteristik Third Place}

Pandangan dari Ray Oldenberg terhadap third place dapat disimpulkan melalui karakteristik berikut :

- Netral (Neutral Ground)

Penghuni tempat ketiga tidak memiliki kewajiban untuk selalu berada di sana. Mereka tidak terikat secara finansial, politik, hukum, atau sebaliknya, dan bebas untuk datang dan pergi sesuka mereka.

- Level (A Leveling Place)

Tempat ketiga tidak mementingkan status individu dalam suatu masyarakat. Status ekonomi atau sosial seseorang tidak diperhitungkan di tempat ketiga sehingga memungkinkan rasa kesamaan di antara penghuninya. Tidak ada persyaratan atau kondisi apapun yang akan mencegah penerimaan atau partisipasi di tempat ketiga.

- Percakapan sebagai Aktivitas Utama

Obrolan yang menyenangkan dan bahagia adalah fokus utama dari aktivitas di tempat ketiga, meskipun tidak harus menjadi satu-satunya aktivitas. Nada percakapan biasanya ringan dan lucu; kecerdasan dan sifat main-main yang baik sangat dihargai.

- Aksesibilitas dan Akomodasi Tempat ketiga harus terbuka dan mudah diakses oleh mereka yang menempatinya. Mereka 
juga harus akomodatif, artinya mereka memenuhi kebutuhan penghuninya, dan semua penghuni merasa kebutuhan mereka telah terpenuhi.

- Pelanggan Tetap

Tempat ketiga memiliki sejumlah pengunjung tetap yang membantu memberi ruang nada, dan membantu mengatur suasana dan karakteristik daerah. Reguler ke tempat ketiga juga menarik pendatang baru, dan ada di sana untuk membantu seseorang yang baru ke ruang merasa diterima dan ditampung.

- Sederhana (Low Profile)

Tempat ketiga merupakan tempat tanpa tinggi hati, kesombongan, maupun keinginan untuk pamer. Tempat ketiga tidak pernah sombong atau sok, dan menerima semua jenis individu, dari berbagai lapisan masyarakat.

- Perasaan Dominan : Playful

Nada percakapan di tempat ketiga tidak pernah ditandai dengan ketegangan atau permusuhan. Sebaliknya, tempat ketiga memiliki sifat yang menyenangkan,

- Rumah diluar Rumah (Home Away from Home)

Penghuni tempat ketiga akan sering memiliki perasaan hangat, kepemilikan, dan kepemilikan yang sama seperti di rumah mereka sendiri. Mereka merasa sepotong diri mereka berakar di ruang, dan mendapatkan regenerasi spiritual dengan menghabiskan waktu di sana.

\section{Space dan Place}

Space (ruang) dan place (tempat) adalah dua kata yang selalu lekat dengan dunia arsitektur. Namun penggunaannya di dalam pembahasan terhadap suatu topik arsitektur tidak jarang terkesan 'campur aduk' sehingga membiaskan makna dari masing---masing kata tersebut.

\section{Pengertian - Yi Fu Tuan}

Berdasarkan salah satu teori yang mendasari keterhubungan antara ruang dan tempat yang diungkapkan oleh Yi Fu Tuan (1979), ruang dan tempat merupakan sifat dasar (nature) dari geografi sebuah lingkungan. Ruang (space) lebih didefinisikan sebagai sebuah hal yang abstrak, sedangkan tempat (place) diartikan sebagai sebuah entitas unik (a special ensemble) yang memiliki sejarah dan makna. Tempat mampu mewujudkan pengalaman dan aspirasi dari masyarakat.

Tempat bukan sekedar fakta yang yang dapat dijelaskan lebih luas dari pemahaman tentang ruang tetapi juga sebuah realitas data yang dapat diklarifikasi dan dimengerti dari cara pandang masyarakat yang memberikan makna sendiri tentang sebuah tempat.

Yi Fu Tuan (1977) berpendapat bahwa ruang lebih abstrak dari tempat. Pendapat ini didasarkan pada kondisi dimana setelah mengalami sebuah ruang, maka individu bisa menangkap nilai - nilai yang hadir di ruang tersebut. Nilai ini yang kemudian menentukan apakah ruang terebut bisa 'menjadi' sebuah tempat atau tidak, bagaimana kondisi yang abstrak tadi bisa menjadi lebih spesifik dan terdefinisikan dengan stabil. Dengan kata lain tempat ditentukan berdasarkan suatu kondisi tertentu yang hadir di sebuah ruang. Ini berarti tempat hanya bisa hadir apabila ada ruang sebagai dasar pembentukannya.

\section{METODE}

\section{Typology}

Roman Bath

Metode pembedahan tipologi dari Roman Bath digunakan untuk mempelajari suatu tempat pemandian umum yang sekaligus menjadi pusat komunitas bagi masyarakat. Berikut di bawah ini adalah diagram kajian tipologi yang sudah dilakukan. 


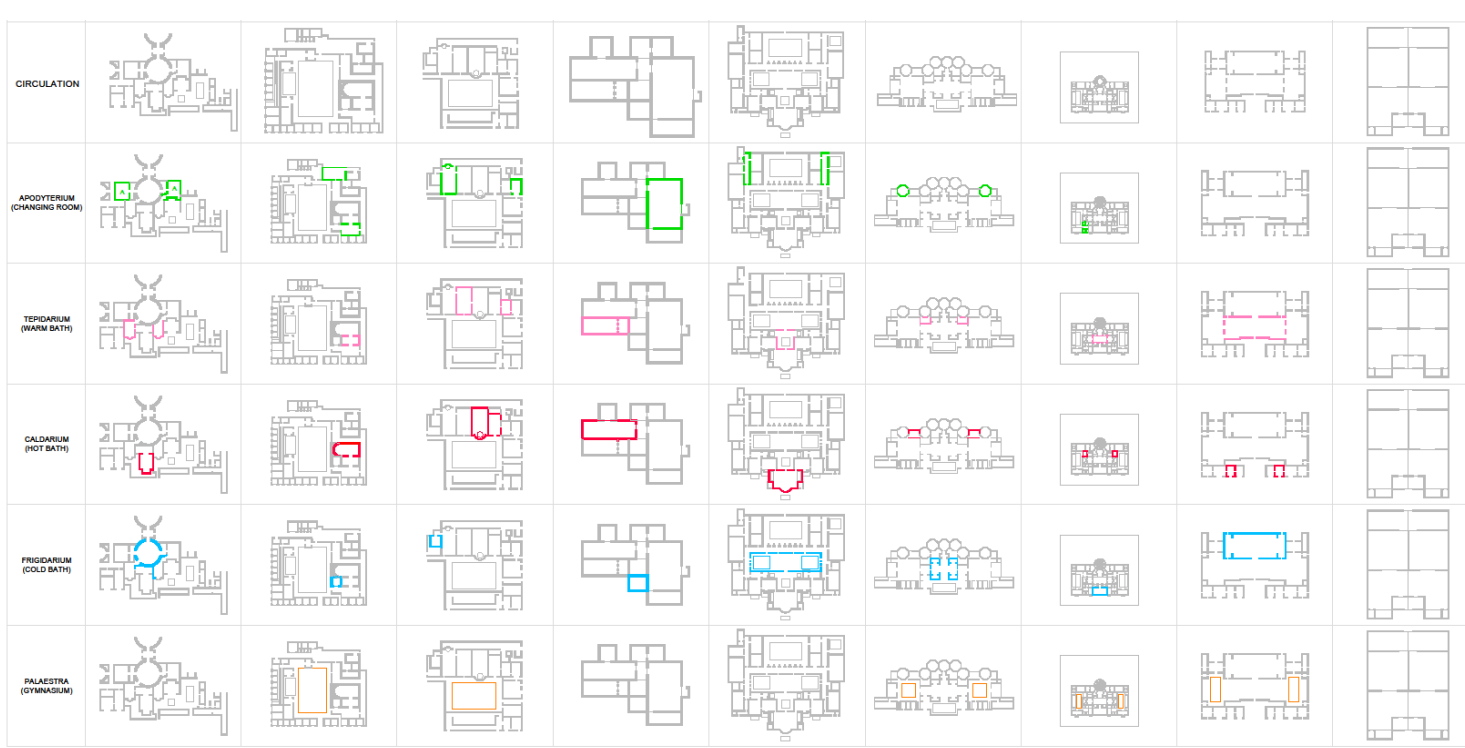

Gambar 1. Diagram Kajian Tipologi Roman Bath Sumber: Penulis, 2020

Tabel pembedahan tipologi Roman Bath di atas diklasifikasikan berdasarkan jenis ruang yang selalu ada di setiap bangunan Roman Bath, yaitu apoditerium (changing room), tepidarium (warm bath), caldarium (hot bath), dan frigidarium (cold bath), serta pintu masuk (entrance) dan gymnasium. Dari proses pembedahan tipologi Roman Bath melalui denah, kita dapat mempelajari pembagian ruang berdasarkan gender, aktivitas, tingkat privasi, serta alur sirkulasi.

\section{Kultur Lokal}

Metode ini digunakan untuk menganalisa cara mandi masyarakat lokal dari berbagai kalangan, yaitu masyarakat menengah ke atas dan menengah ke bawah, kemudian mensintesa berbagai cara mandi yang terjadi dalam masyarakat untuk diadopsi sebagai sistem mandi dalam projek.

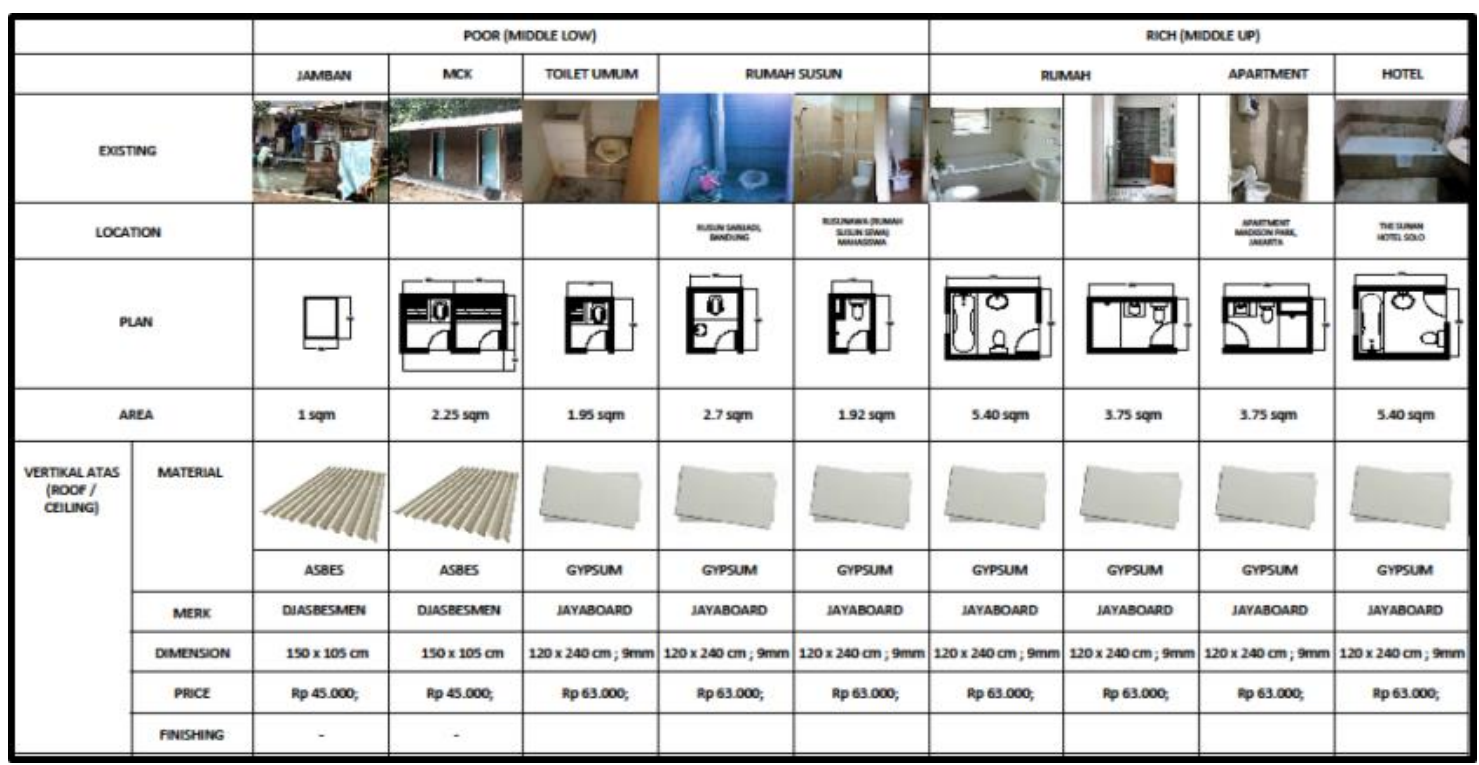

Gambar 2. Diagram Kajian Kamar mandi Lokal Sumber: Penulis, 2020 
Berikut merupakan tabel yang menjabarkan tipe kamar mandi dari masyarakat menengah ke bawah hingga menengah ke atas, dengan membedah elemen arsitektur pembentuknya seperti dinding, pintu, plafon, dan atap yang dilengkapi dengan ukuran per unit serta tipe dan merk.

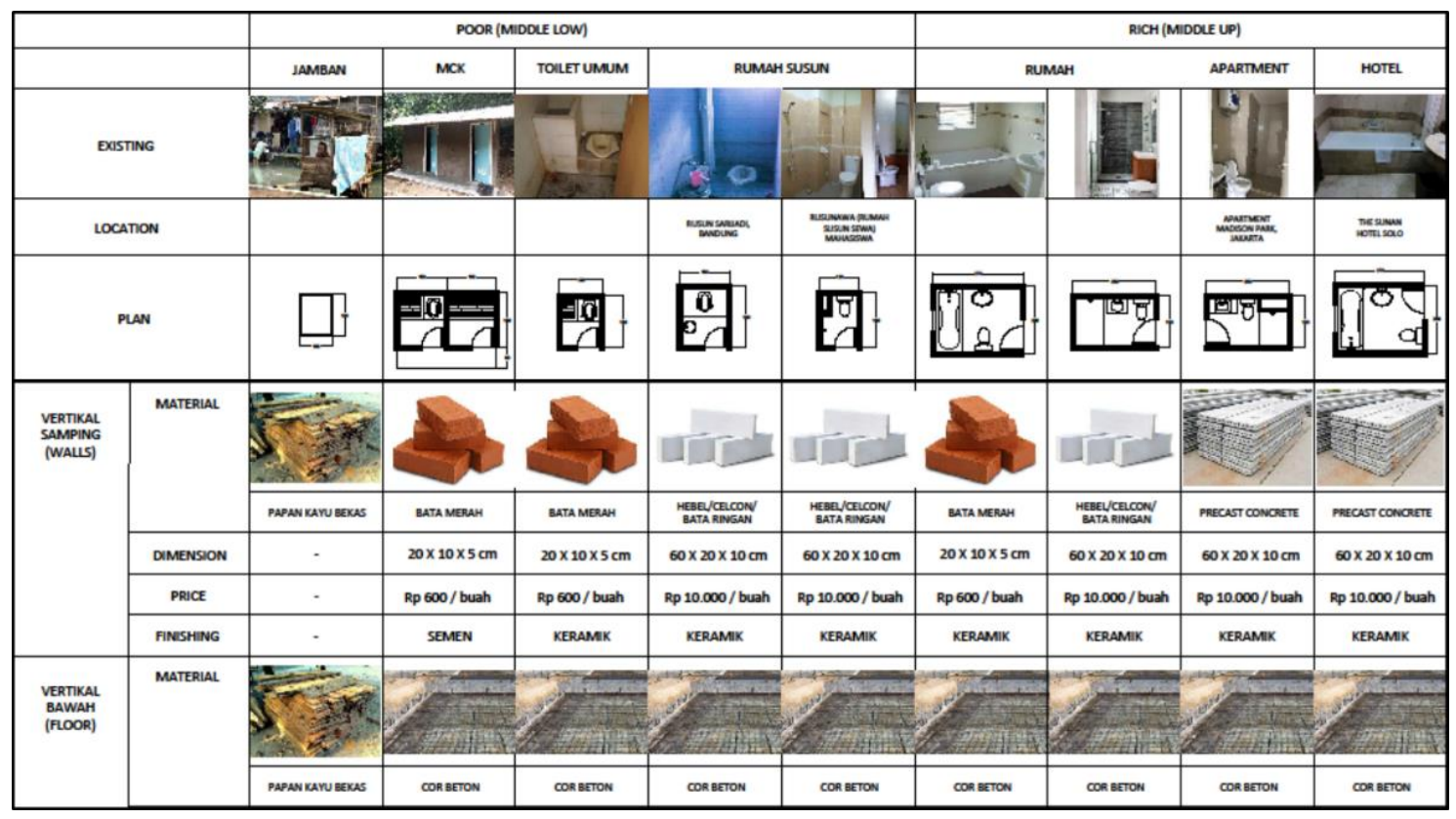

Gambar 3.Diagram Kajian Kamar mandi Lokal Sumber: Penulis, 2020

\section{Studi Lapangan}

Projek ini mengusulkan sebuah prototipe Public Bath (pemandian umum) yang apabila direplikasi, dapat membantu permasalahan krisis air skala nasional. Namun sebagai tempat yang menjawab kebutuhan dasar publik, maka Public Bath harus memiliki akses yang mudah dicapai oleh seluruh masyarakat yang dilayaninya, sehingga mengharuskan Public Bath untuk berada di pusat (centre) kawasan terkait.

Melihat kebutuhan penting dari Public Bath yang serupa dengan kebutuhan Ruang Terbuka Hijau (RTH), dimana keduanya sama - sama dibutuhkan di tengah - tengah masyarakat dengan radius yang mudah dicapai pejalan kaki, maka projek ini melihat adanya potensi RTH sebagai lokasi public bath.

Pembangunan pada area Ruang Terbuka Hijau merupakan pelanggaran Undang - Undang, karena Ruang Terbuka Hijau dianggap (dan seharusnya) sebagai area resapan air, paru - paru kota, dan mendukung berbagai kegiatan komunitas terutama di bidang sosial. Namun pada kenyataannya, apakah benar area Ruang Terbuka Hijau 80\% merupakan area resapan air seperti ketentuan minimal dalam Undang - Undang? Apakah Ruang Terbuka Hijau dibutuhkan masyarakat lebih dari sekedar penyegar udara (paru - paru kota)?

Karena itu sebelum memutuskan pemilihan tapak pada area RTH, ada berbagai hipotesa terhadap tapak (existing) terkait dengan peraturan serta realita kegiatan masyarakat, yang apabila hipotesa tersebut 'benar', sudah cukup untuk mengusulkan perubahan terhadap Ruang Terbuka Hijau, atau penambahan jenis RTH dalam peraturan, tanpa menghilangkan atau mengurangi esensi Ruang Terbuka Hijau. Berikut merupakan hipotesa terhadap Ruang Terbuka Hijau (existing) :

a. Ruang Terbuka Hijau tidak memenuhi standar resapan air.

b. Ruang Terbuka Hijau gersang.

c. Ruang Terbuka Hijau tidak ramah anak

d. Ruang Terbuka Hijau sepi pengunjung / jarang dikunjungi. 


\section{DISKUSI DAN HASIL}

Berdasarkan hasil pengumpulan data melalui observasi dan wawancara, keempat hipotesa diatas dinyatakan 'benar'. Hal ini diperkuat dengan hasil yang menyatakan bahwa kondisi taman memang jarang dikunjungi kecuali pada sore hari. Projek ini mengusulkan sebuah tipe baru hasil dari mutasi antara Bath House dan Park. Dalam hal ini, pemandian umum 'menumpang' pada lokasi RTH, bukanlah sebagai 'parasit', justru sebaliknya menciptakan hubungan simbiosis mutualisme (saling menguntungkan). Berikut merupakan hasil hubungan simbiosis mutualisme antara Bath House dan Park:

a. Ruang Terbuka Hijau (Park) terhadap Public Bath

+ Memiliki lokasi yang strategis dan terpusat sehingga memudahkan pencapaian.

b. 2. Public Bath terhadap Ruang Terbuka Hijau

+ Mengusulkan desain yang menawarkan area resapan lebih besar daripada existing. $(>60 \%)$

+ Menyediakan area hijau hingga $>100 \%$ daripada existing dengan menawarkan desain area hijau lebih dari 1 layer (lapisan)

+ Kebutuhan masyarakat akan air menjadi penarik awal bagi orang untuk datang. (Teori Kebutuhan Maslow)

+ Kehadiran Public Bath menjadi katalisator bagi park terutama dalam hubungan sosial antar tetangga yang individualistis dan apatis untuk saling bertemu dan berinteraksi.

Visi untuk menghadirkan ruang hijau melebihi existing diimplementasikan dalam proses desain melalui double layer, dimana layer terbawah (underground) hanya dilakukan perkerasan pada area pool bath, dan selebihnya merupakan area hijau dan area resapan air.

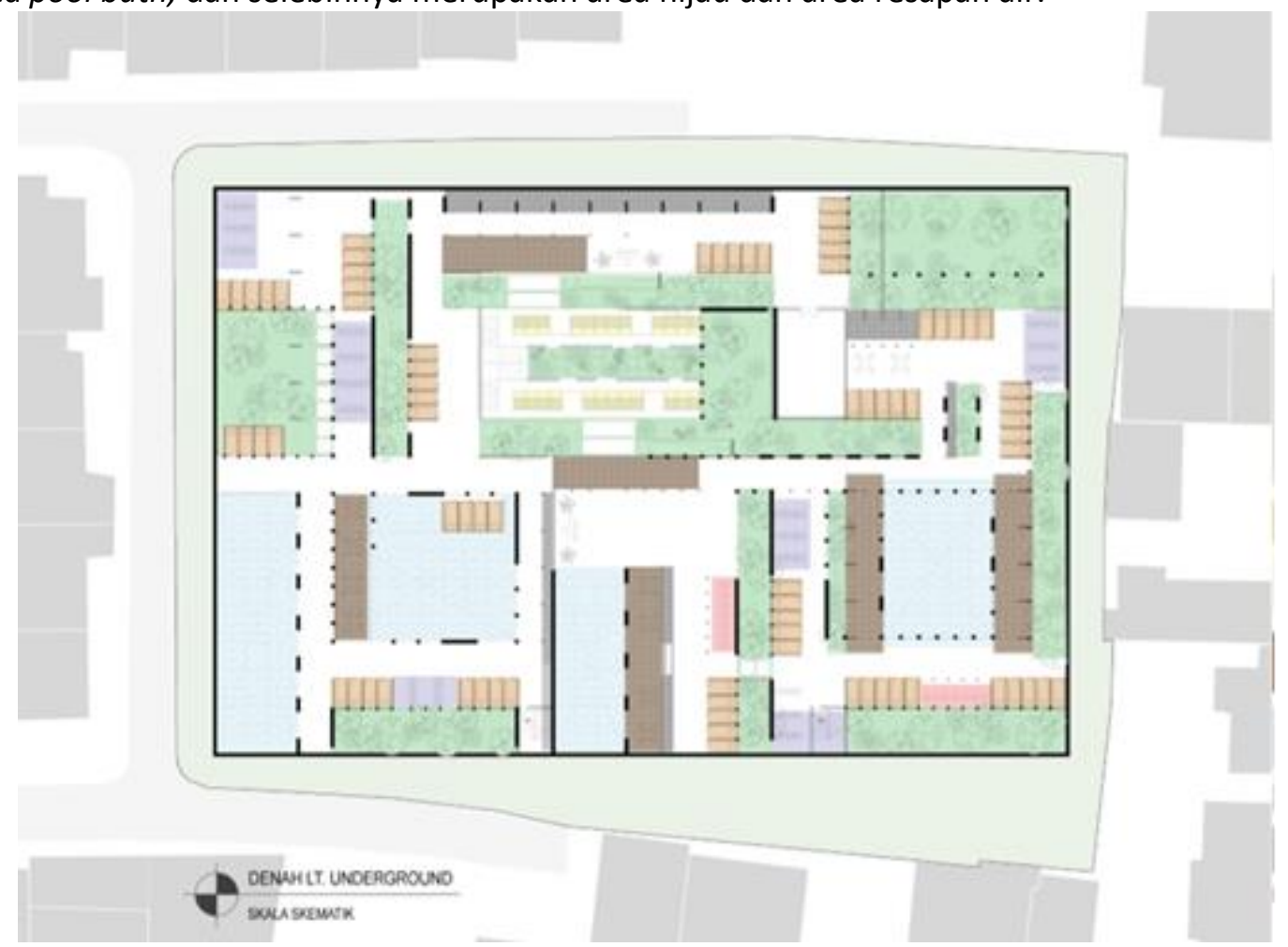

Gambar 4.Denah Programatik LT.UG

Sumber: Penulis, 2020

Pusat aktivitas pemandian umum diletakkan pada layer underground dengan tujuan privasi namun tetap terbuka dengan ruang hijau, serta untuk meminimalkan tingkat kecepatan angin bagi pengunjung yang melakukan kegiatan mandi ataupun berendam. 


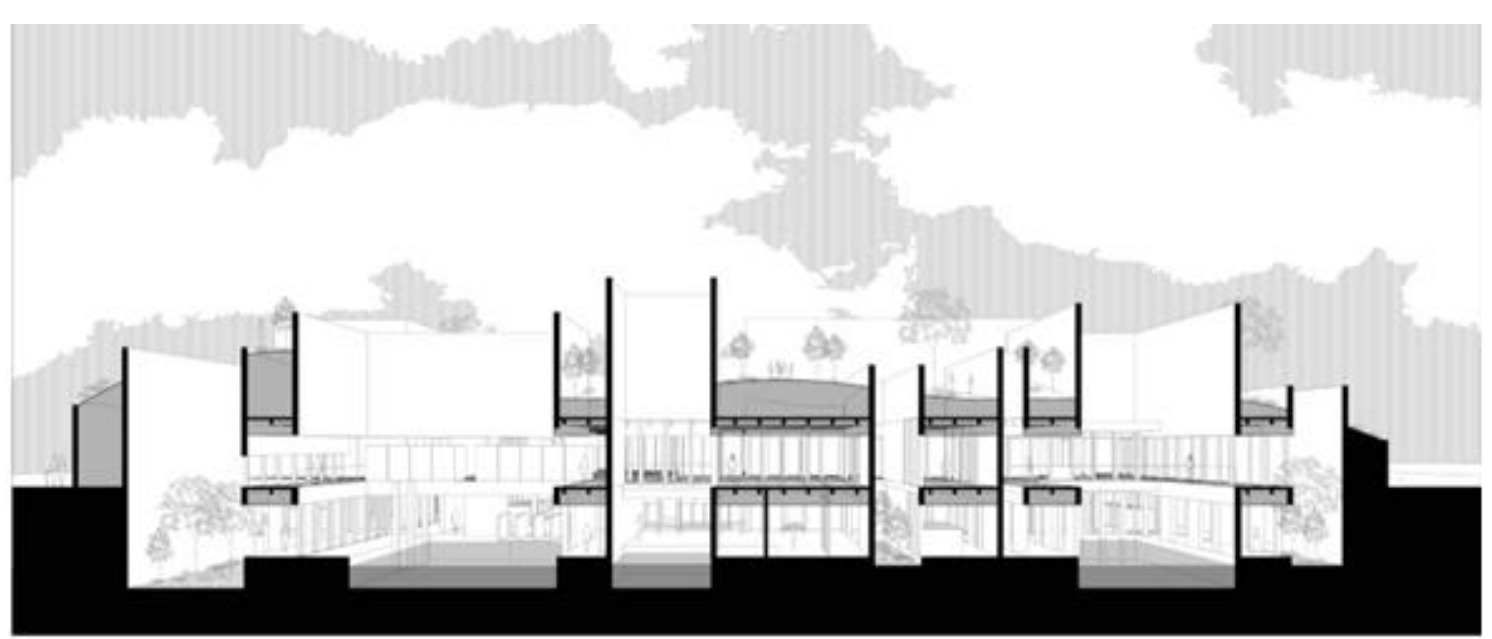

Gambar 5. Potongan Perspektif

Sumber: Penulis, 2020

Pembagian zonasi utama pada layer underground didasarkan pada perbedaan gender. Warna merah muda mewakili area wanita sedangkan warna biru muda mewakili area pria. Terdapat dua jenis cara mandi, yaitu shower serta pool bath. Cara mandi dalam Bath House didominasi dengan ruang kubikal shower dikarenakan cara mandi dengan shower menggunakan air paling minimum dibandingan cara mandi dengan menggunakan gayung ataupun bathtub. Seluruh kubikal shower menghadap ke ruang hijau langsung dengan elemen dinding pemisah double mirror, sehingga individu yang mandi dapat merasakan nuansa area hijau yang ada diluar secara visual dari dalam, namun tidak dapat ditembus secara visual oleh individu-individu yang berada di luar.

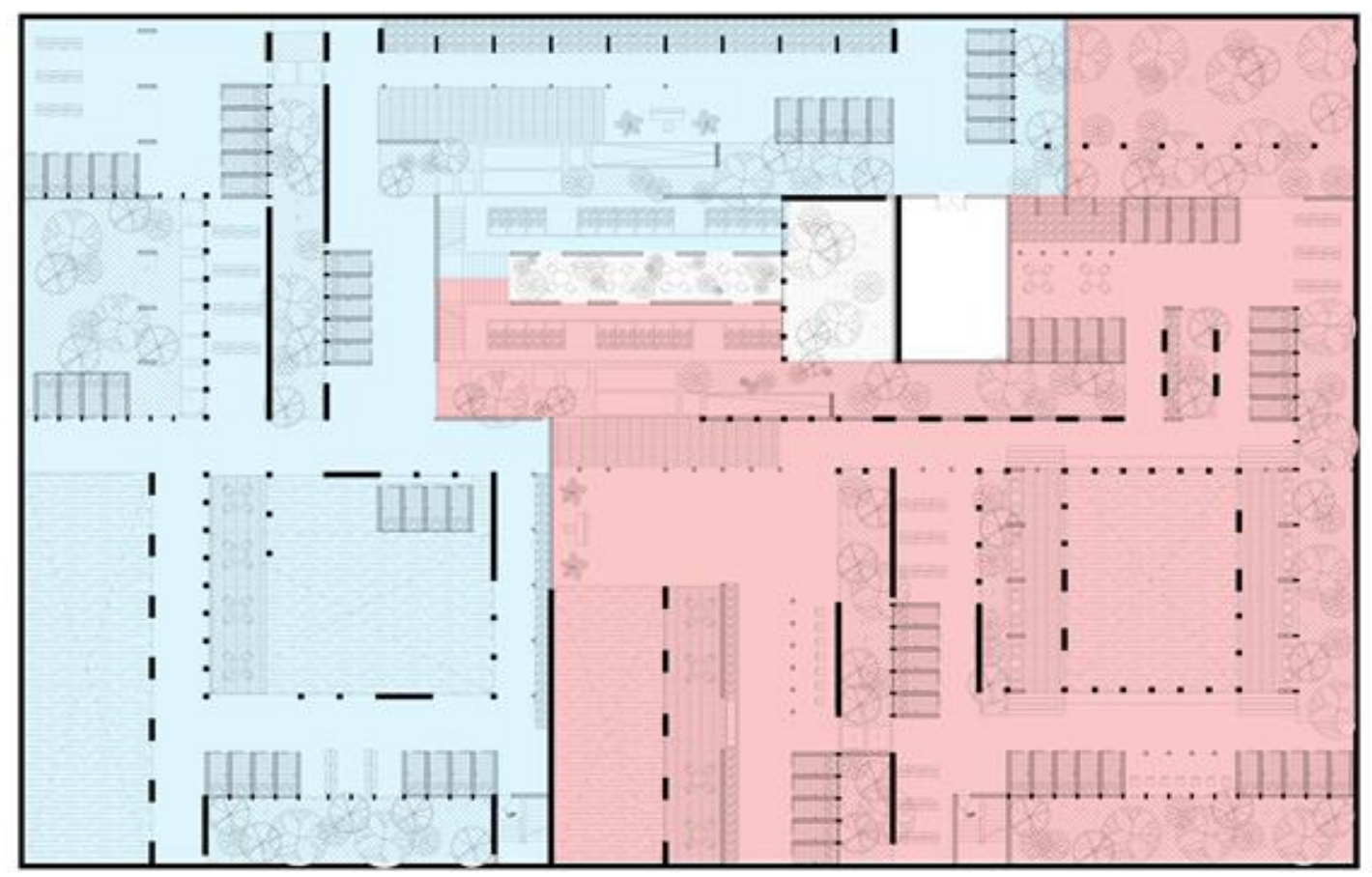

Gambar 6. Pembagian Area Underground Berdasarkan Gender.

Sumber: Penulis, 2020 


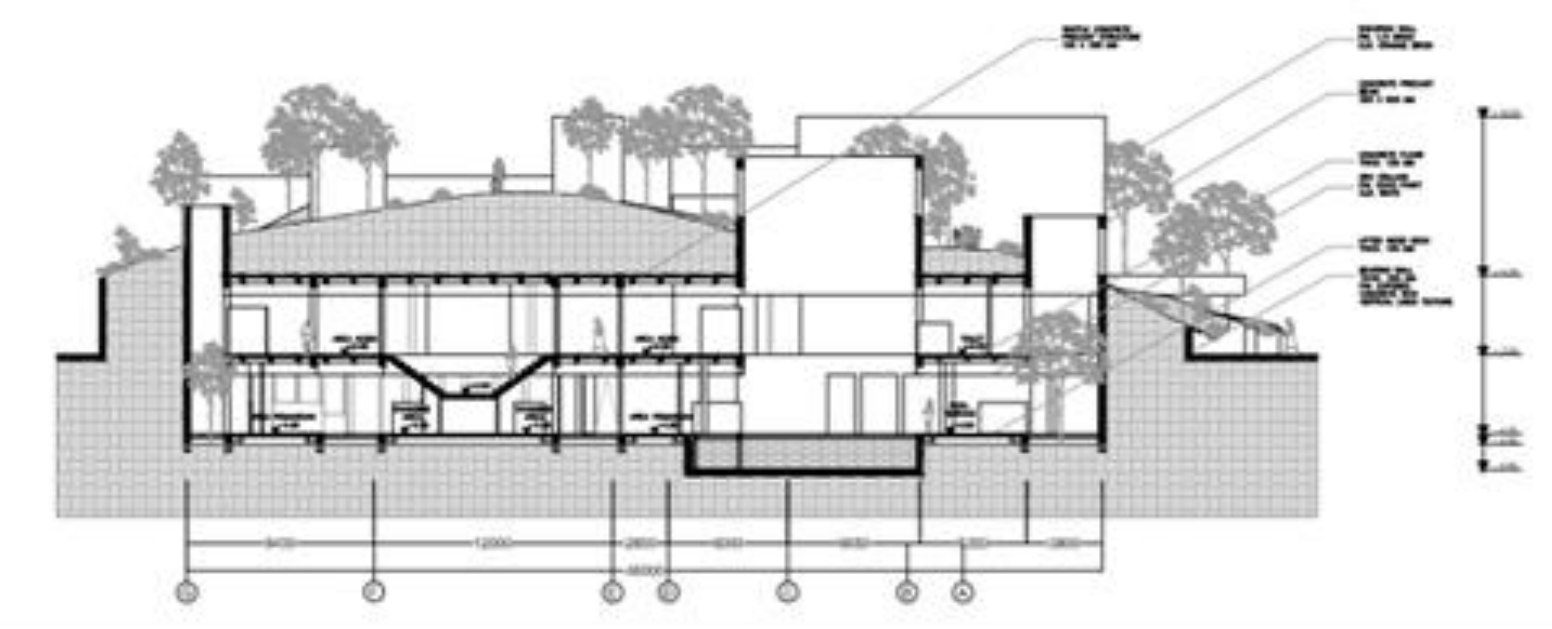

Gambar 7. Potongan Bangunan

Sumber: Penulis, 2020

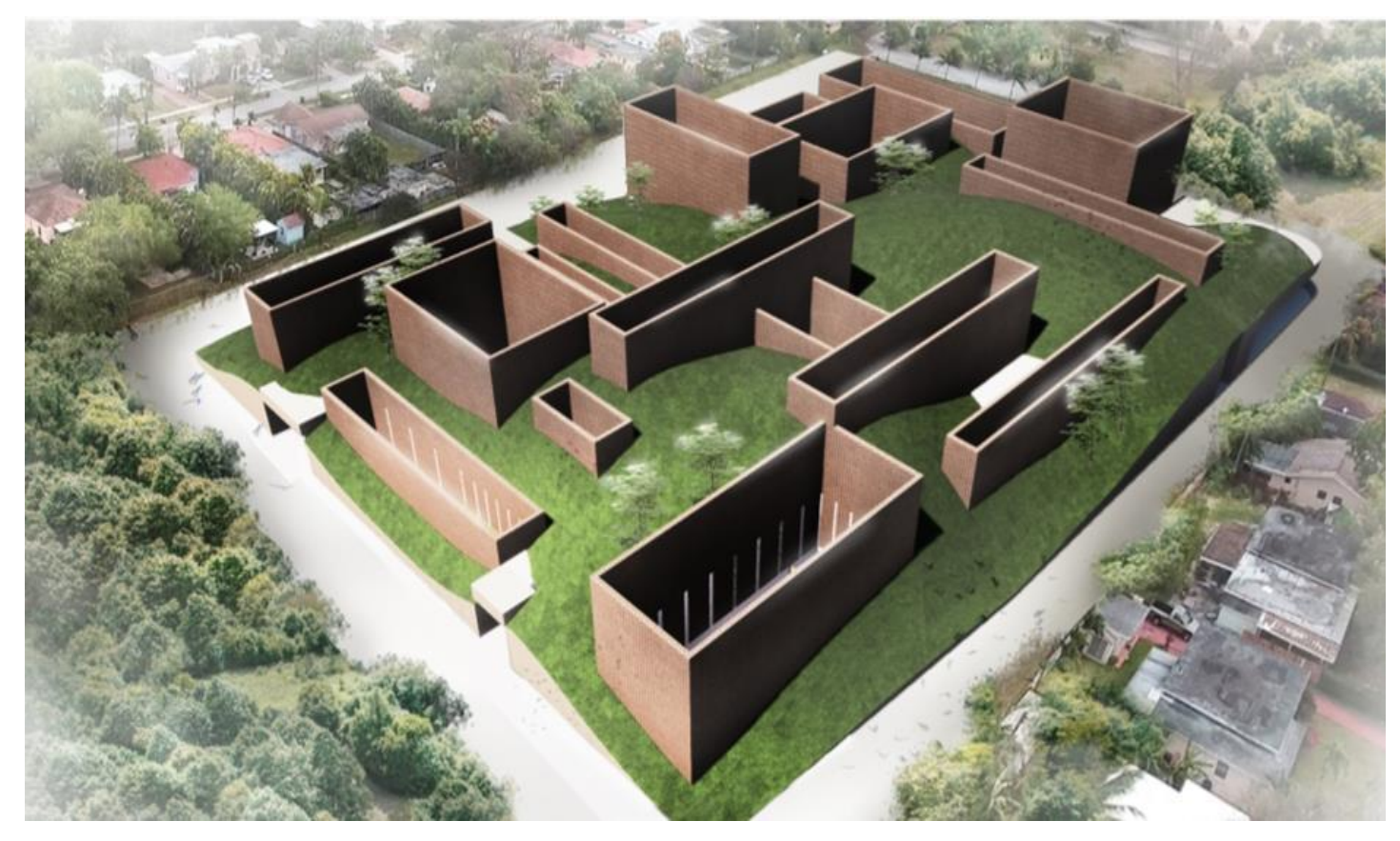

Gambar 8. Perspektif Eksterior

Sumber: Penulis, 2020

Bangunan Public Bath secara eksterior didominasi oleh kehadiran void-void yang menjadi akses langsung bagi cahaya matahari serta sirkulasi udara menuju ke underground sehingga area mandi pada layer underground tidak lembab dan mendapat pencahayaan alami yang cukup. Dinding- dinding void memiliki ketinggian yang bervariasi dan memiliki fungsi yang beragam. Sebagian dinding void yang rendah menjadi railing pembatas bagi pengunjung untuk bisa melihat ke layer dibawahnya. Dinding yang lebih tinggi selain berfungsi untuk membatasi secara visual beberapa area di layer bawahnya, juga sebagai shading pada area taman sehingga menjawab permasalahan existing, yaitu sepinya pengunjung dikarenakan teriknya matahari di siang hari. 

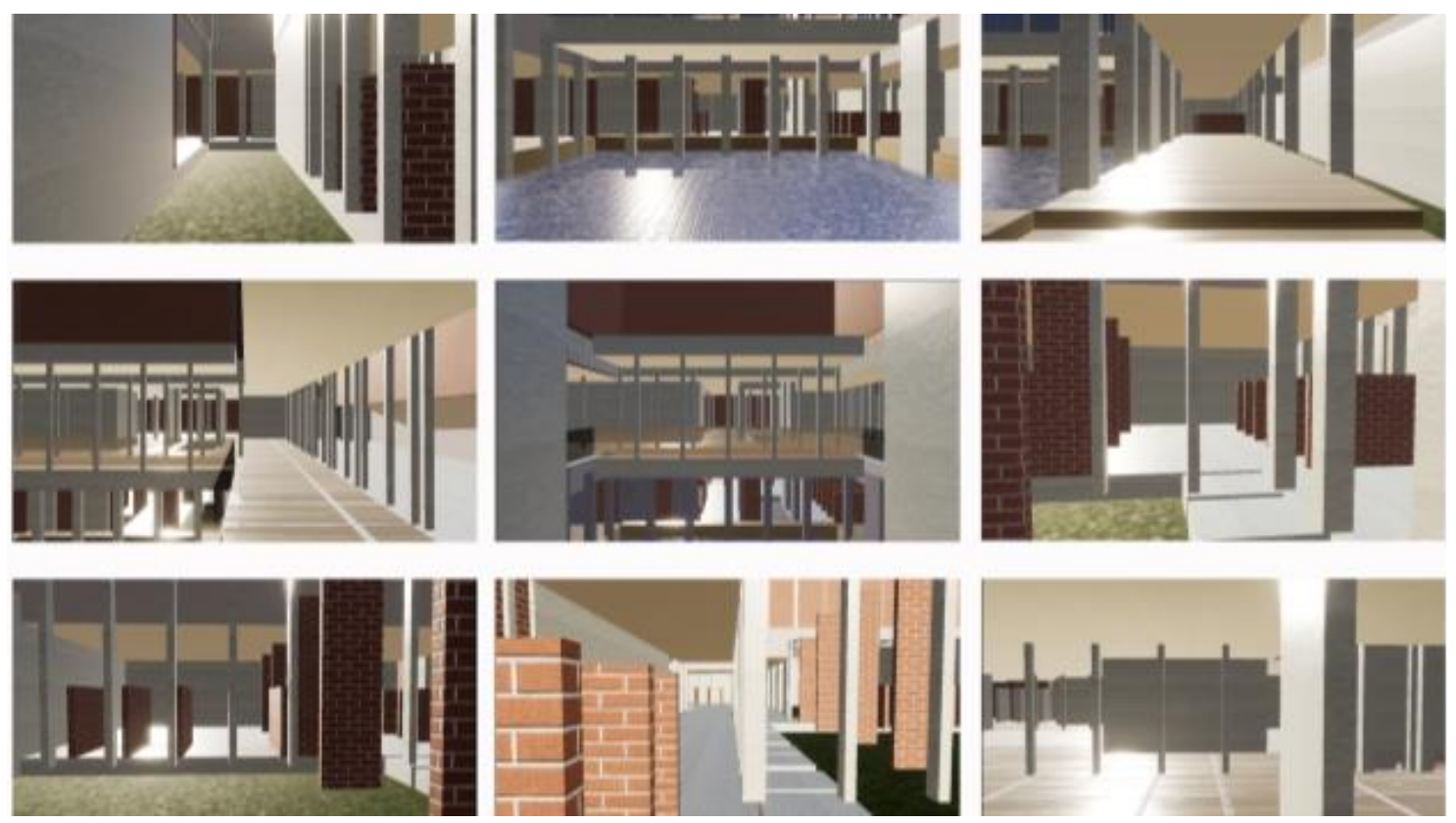

Gambar 9. Perspektif Interior Sumber: Penulis, 2020

\section{KESIMPULAN DAN SARAN}

Projek ini didasari oleh sebuah isu kebutuhan fisiologi, yaitu isu krisis air dimana PDAM tidak memiliki pasokan sumber air bersih yang cukup untuk memenuhi kebutuhan masyarakat Jakarta sehingga 40\% masyarakat menggunakan air tanah. Pengambilan pasokan air tanah secara besar-besaran mengakibatkan penururan muka tanah yang signifikan sehingga mengancam tenggelamnya Jakarta pada tahun 2050. Sehingga dibutuhkan solusi untuk mengatasi permasalahan kualitas, kuantitas serta distribusi air. Maka projek ini mengusulkan sebuah Public Bath (pemandian umum) dimana kualitas dan kuantitas pemakaian air dapat terkontrol sehingga air dapat didaur ulang tanpa mengurangi kualitas air dan pasokan air dapat tersebar secara merata melalui distribusi kolektif.

Melihat adanya kebutuhan Public Bath yang harus mudah diakses dan dekat untuk dijangkau dari berbagai sisi, maka Ruang Terbuka Hijau dipilih sebagai lokasi yang ideal dengan terlebih dahulu mengkaji kembali tujuan keberadaan Ruang Terbuka Hijau tanpa menghilangkan esensi yang sesungguhnya, sekaligus meningkatkan produktivitas Ruang Terbuka Hijau dengan menawarkan penggunaan lahan bersamaan sehingga menghasilkan suatu prototype baru hasil dari mutasi antara Public Bath dan Park.

Bath House and Park Prototype dapat dikategorikan sebagai third place karena memiliki karakteristik sebagai third place seperti yang disebutkan oleh Ray Oldenberg dalam bukunya "The Great Good Place", yaitu tempat berkumpulnya orang yang asing satu sama lain dalam kebutuhan yang sama dan beragam. Tempat dimana orang yang tidak saling mengenal, bertemu dalam frekuensi tertentu sehingga mereka menjadi saling mengenal dan menjadi akrab sehingga menjadi community centre (pusat komunitas).

\section{REFERENSI}

Abdurahman, O. 2014, Air Tanah Jakarta: Air Diambil, Angka Dicatat, diunduh 14 Agustus 2019, <http://geomagz.geologi.esdm.go.id/air-tanah-jakarta-air-diambil-angka-dicatat/ Beall. J (1997). A City for All. London: Zed Books.

Bimo, Harwanto 2017, Pemerintah ungkap DKI krisis air bersih, Jakarta Utara terparah, diunduh 6 Agustus 2019, <https://www.merdeka.com/uang/pemerintah-ungkap-dki-krisisair-bersih-jakarta-utara-terparah.html 
Kartika, Mimi 2019, Anies: 40 Persen Warga Jakarta Belum Akses Air Bersih, diunduh 2 September 2019, <https://www.republika.co.id/berita/nasional/jabodetabeknasional/19/02/18/pn427a335-anies-40-persen-warga-jakarta-belum-akses-air-bersih

Maharani, Dian 2019, Pipa Air di Jakarta Bocor hingga 44,3 Persen Per Tahun, diunduh 5 Agustus 2019, <https://megapolitan.kompas.com/read/2019/02/18/19595531/pipa-air-dijakarta-bocor-hingga-443-persen-per-tahun

Oldenburg. R (1989). The Great Good Place: Cafes, Coffee Shops, Community Centers, Beauty Parlors, General Stores, Bars, Hangouts, and How They Get You Through the Day. New York: Paragon House.

Panggabean, Gemal 2017, Kementerian ESDM : Jakarta Krisis Air Bersih, diunduh 28 Agustus 2019 <https://jakarta.bisnis.com/read/20170611/77/661299/kementerian-esdm-jakartakrisis-air-bersih

Qomaria,Rostanti 2014, Penggunaan Air di Rumah Tangga Picu Kelangkaan Air Bersih, diunduh 27 Agustus 2019 <https://www.republika.co.id/berita/nasional/umum/14/03/24/n2x3pqpenggunaan-air-di-rumah-tangga-picu-kelangkaan-air-bersihSulistijowati (1991). Tipologi Arsitektur pada Rumah Kolonial, Surabaya. Dengan Kasus Perumahan Plampitan dan sekitarnya.

Rizkika, Siti 2014, Indonesia Bisa Mengalami Krisis Air Tahun 2025, diunduh 27 Agustus 2019, $<$ https://www.beritasatu.com/kesra/173180-indonesia-bisa-mengalami-krisis-air-tahun2025.html

Setiyadi, Bima, 2018, DKI Genjot Air Bersih Melalui Sumber Air Jakarta, diunduh 28 Agustus 2019, <https://metro.sindonews.com/read/1336352/171/dki-genjot-air-bersih-melaluisumber-air-jakarta-1536265401

Sunu,Aloysius, 2019, Sebanyak 13 Sungai di Jakarta, Airnya Belum Layak Dijadikan Bahan Baku $\begin{array}{lllll}\text { Air Bersih, } & 28 & \text { diunduh }\end{array}$ <https://wartakota.tribunnews.com/2019/03/21/sebanyak-13-sungai-di-jakarta-airnyabelum-layak-dijadikan-bahan-baku-air-bersih

Tjahyono. G. (2000). Metode Perancangan. Depok: Universitas Indonesia.

Yusuf, Yan 2018, Intrusi Air Laut, Air Tanah di Jakarta Barat dan Utara Jadi Asin, diunduh 12 Agustus 2019, <https://metro.sindonews.com/read/1336951/171/intrusi-air-laut-airtanah-di-jakarta-barat-dan-utara-jadi-asin-1536495158 
